\title{
Holistic Modelling Approach for the Management of Organisations
}

\author{
Harald Kitzmann ${ }^{1,2}$ \\ ${ }^{1}$ Bauman Moscow State Technical University, 105005, 2nd Baumanskaya St., 5, building 1, Moscow, \\ Russian Federation \\ ${ }^{2}$ Estonian Association for Renewable Energy, Estonia
}

\begin{abstract}
Developments in digitalization are in actual scientific discussion with leading focus on the automatizing of tasks especially in managers' decision making, but also cover the view on the daily managerial taskfulfilment with digitalized solutions. Challenge for the managers is hereby the design of the digitalized work in a human-task-technology system by using advanced working models, methods and solutions. This compels to rethink causal-deterministic approaches and find new solutions, which especially occur in tasks of the strategic management. The purpose of this study was twofold. The first target was to identify and analyse the models and characteristics of strategic management decisions using approaches of the system theory, cybernetic management, and quantum theory. The second aim was to outline a framework of design parameters for creating causaldeterministic and holistic approaches in complex and complementary decision situations, so that they can be designed and processed digitally and implemented into human-task-technology systems, with outline the way how managerial decision-making will be changed. Keywords: complementary decision, dual process theory, strategic management, quantum decision theory, system theory, cybernetic management
\end{abstract}

It is proceeded as follows. First, the theoretical background to the study is outlined. It will be described the structural element in decision making as well as management of complex situations, paying special attention to complementary characteristics of decisions on the strategical and operational management level. Secondly, in the study it will be also examined different modelling approaches for solving complex and complementary decision situations. Building on this theoretical background, then, third it will be characterised the holistic, cybernetic modelling set-up and its transformation directions as appropriate approach for implementing into advanced digital solutions using the method engineering model. Then it will be discussed the derived framework as well as potential development areas in implementing the modelling approach, including the potential impact on decision situations and tasks, as well as impact on the needed competencies of users working with the improved solutions.

Considering the tripartite structure of decision making in a human-task-technology system, digitized solutions are not limited to the improving of the information processing, but also on the improving the dialogue interface, the improving of the competencies of users working with improved tools and the improved tasks and task solving in the organisations 
$[1,2]$. This transformation process and its impact on elements in the organisational knowledge system are shown in Figure 1.

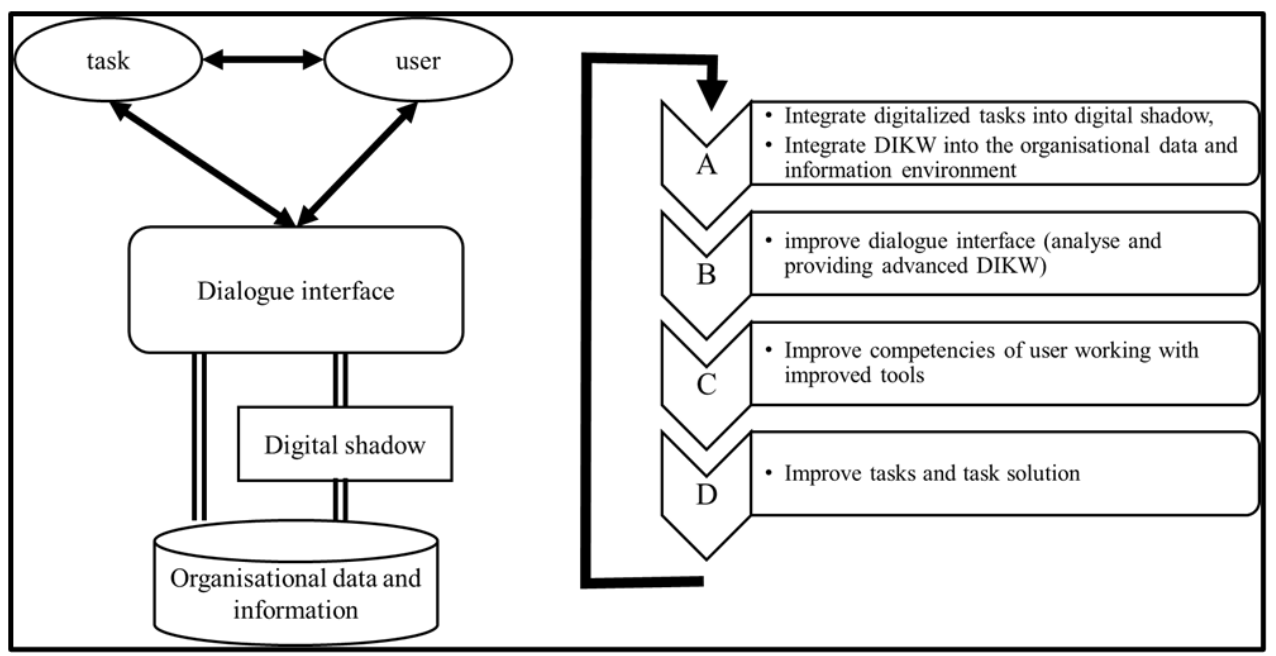

Fig. 1. Digitalization in the organisational knowledge system

Prerequisite for digitalization of management activity is the creation of theoretical concepts in supporting describing, explaining, prediction, simulation, decision, optimizing and gives orientation and reflection of the activities [3]. Hereby it should be considered modelling case, organization and situation-based individual, dynamical and process depending elements $[4,5]$, the modelling of the decision making-process on different management levels $[6,7,8]$, the modelling of the cognitive process of intuition and deliberation in decision-making [9-15], as well as the tight integration of human decision activities and technology support [16-19]. These requirements find their implementation in advances holistic modelling solutions based on the dual-theory in decision making, the tripartite modelling set-up, simultaneous management and dynamic screenplay approaches.

The EMO model (environment-management-organisation model) is a generic metamodel framework that allows to represent the participating, as well as observing and observed dimensions of cybernetic systems, but also allows to view, analyse and design situation- and decision-specific individualized elements as well as the whole system. In the model are described internal situations and processes on normative, strategic and operative level following different approaches of causality, correlation and complementary. The results in the management processes have impact on the element management, as well as on the interconnection with the environment and the design of the element organisation, which are designed as development modes, structuring forces, management practice, orientation level and value creation.

Understandings in strategic management consist of a time-dependent view with orientation to the future situation and a time-independent view focusing on the design of potential and the ways how to use the potential [3, 20-23]. The time-dependent view is discussed in cybernetics and systems theory with the present situation and their three attractors of development: optimizing equilibrium (stable equilibrium and steady state), instability and bounded instability. Schwaninger and Gälweiler developed a timeindependent view in strategic management as a framework of control variables and identified depending on the management level differences in the purpose of these variables, their types and goals representing. The combination of time-dependent and time-independent view is already established in the Viable System Model (VSM Model) by Stafford Beer [20], 
National Automated System for Computation and Information Processing (OGAS) [24], the Theory of Functional Systems [25], the sensitivity model by Vester [26], and the systemic economy [27]. But these models transfer the complex and qualitative characteristics into operational figures to handle them in deterministic-causal, data-driven analysis, without considering dualistic, complementary effects in decision making and processes in organisations. Therefore, the main understandings in strategic management were fragmented into different modules, whereas were found analogies and similarities in different scientific disciplines. Mainly these approaches are of a complementary character, but also extend traditional approaches with additional dimensions, and quantum mechanics approaches for different modelling set-up (Table 1).

Table 1. Approaches solving strategic management decision situations

\begin{tabular}{|c|c|c|}
\hline $\begin{array}{l}\text { Characteristics of } \\
\text { complementary } \\
\text { management }\end{array}$ & Attributes & Modelling approaches \\
\hline \multirow[t]{2}{*}{$\begin{array}{l}\text { Time-dependent } \\
\text { view of } \\
\text { development }\end{array}$} & $\begin{array}{l}\text { Stability, optimizing, steady } \\
\text { state, homeostasis }\end{array}$ & $\begin{array}{ll}\text { Causal-deterministic } & \\
\text { approaches, } & \text { classical } \\
\text { mathematics, physics } & \\
\end{array}$ \\
\hline & $\begin{array}{l}\text { bounded instability } \\
\text { (alternating between stability } \\
\text { and instability) }\end{array}$ & $\begin{array}{lrr}\text { Alternating } & \text { of } & \text { causal- } \\
\text { deterministic } & \text { and } & \text { non-causal } \\
\text { dynamics } & & \end{array}$ \\
\hline \multirow[t]{2}{*}{$\begin{array}{l}\text { Time-independent } \\
\text { view of } \\
\text { development }\end{array}$} & $\begin{array}{l}\text { Complementary of status and } \\
\text { development direction of } \\
\text { objects }\end{array}$ & $\begin{array}{l}\text { Particle-wave approach in } \\
\text { (quantum) physics }\end{array}$ \\
\hline & $\begin{array}{l}\text { Complementary of potential } \\
\text { design and potential usage }\end{array}$ & Law on conservation of energy \\
\hline \multirow[t]{3}{*}{ Measures } & $\begin{array}{l}\text { Discrete and } \text { Extended } \\
\text { measures on the operative } \\
\text { management level }\end{array}$ & $\begin{array}{lll}\begin{array}{l}\text { Flexibility } \\
\text { mathematics }\end{array} & \text { cube; interval } \\
\end{array}$ \\
\hline & Non mathematical measures & "hermeneutic" interpretation \\
\hline & Complex measure & $\begin{array}{l}\text { One dimensional and multi- } \\
\text { dimensional (e.g. Hilbert space) }\end{array}$ \\
\hline $\begin{array}{l}\text { Situation set-up and } \\
\text { solving }\end{array}$ & $\begin{array}{l}\text { Complementary of causal- } \\
\text { deterministic and non-causal } \\
\text { behaviour }\end{array}$ & Quantum decision theory \\
\hline \multirow[t]{4}{*}{$\begin{array}{l}\text { Integral set of } \\
\text { management } \\
\text { variables }\end{array}$} & $\begin{array}{l}\text { Types interactions between } \\
\text { three participants is reasoning } \\
\text { the improvements }\end{array}$ & $\begin{array}{l}\text { GHZ modelling set-up, } \\
\text { Entanglement measure }\end{array}$ \\
\hline & $\begin{array}{l}\text { Integral set of objectives and } \\
\text { actuating variables }\end{array}$ & $\begin{array}{l}\text { Complementary cybernetics, } \\
\text { System Dynamics }\end{array}$ \\
\hline & $\begin{array}{lcr}\begin{array}{l}\text { inseparable } \\
\text { environment, } \\
\text { scenarios }\end{array} & \begin{array}{c}\text { unit } \\
\text { process }\end{array} & \begin{array}{r}\text { of } \\
\text { and }\end{array} \\
\end{array}$ & $\begin{array}{l}\text { Screenplay approaches } \\
\text { Dynamic Vector Logistics of } \\
\text { Processes }\end{array}$ \\
\hline & $\begin{array}{l}\text { Integral set of elements and } \\
\text { their connection }\end{array}$ & System theory \\
\hline
\end{tabular}

Beside the implementation of (weak and strong) Artificial Intelligence methods as subject in curricula, the interdisciplinary (especially from biological, chemical and quantum physic science) and cross-functional thinking and modelling, as well as the non-causal dynamic modelling, thinking in complex and fractal structures, dualistic thinking and modelling of combined deterministic and non-causal processes will be in the future found as learning outcomes in curricula and training programs. These aspects are challenging questions to be 
answered by national and international bodies (qualification frameworks, qualifications standards), professional bodies (occupational profiles and standards) and educational bodies (curricula and assessment specifications) as the stakeholders in the educational process.

The study shows that the complexity of decision situations allows using different proper solving methodologies with different reliable and suitable results, as well as enables and recommends continuous reviewing the design of decision situations. Furthermore, it underlines on one hand the organisational and time specific individualised character of strategic management decision situations. On the other hand, it revealed the reciprocal dependency between semantics, procedural model of the digitalized tasks and the user of the digitalized environment.

The research result closes the gap in finding implementation approaches for supporting the management in solving complex decision situations considering holistic system understandings and highlights the development areas for novel ideas and interdisciplinary transfer of knowledge developed in other scientific disciplines.

\section{References}

1. F. Fossen, A. Sorgner, Foresight and STI Governance, 13(2), 10-18. doi:https://doi.org/10.17323/2500-2597.2019.2.10.18 (2019)

2. S. G. Falko, V.V. Yatsenko, Компетенции персонала в условиях циифровизации экономики. Информационное общество и ичировая экономика: глобальные трансформачии, 286-294, Krasnodar (2019).

3. J. Rüegg-StürmGrand, S. Das, St. Galler, Management-Modell-Management in einer komplexen Welt (2. Auflage ed.) (Bern, Haupt Verlag, 2020).

4. Jacobsen, L. Bestimmungsfaktoren für Erfolg in Entrepreneurship (Berlin, Freie Universität Berlin Hochschulschriften, 2003).

5. J. F. Urbánek, D. Král, Modelling and implementation of added value controlling in small and middle enterprises continuity (Prague, University of Finance and Administration Prague, 2014).

6. R. Stacey, Managing the Unknowable: Strategic Boundaries Between Order and Chaos in Organizations (John Wiley \& Sons, 1992).

7. W. Ashby, An introduction to cybernetics (London, Champan \& Hall Ltd., 1957).

8. Н. Kitzmann, Разработка модели управления гибкостью предприятия на оперативном и стратегическом уровне (Moscow, 2018).

9. S. Milli, F. Lieder, T. Griffiths, A Rational Reinterpretation of Dual-Process Theories (2018).

10. G. Gronchi, F. Giovannelli, Front Psychol., 9, 1237. doi:https://doi.org/10.3389/fpsyg.2018.01237 (2018).

11. V.I. Yukalov, D. Sornette, How brains make decisions, in Springer Proceedings in Physics. Universe of Scales: From Nanotechnology to Cosmology. 150, 37-53 (2014).

12. M. Farjoun, Academy of Management Review, 35(2), 202-225 (2010).

13. A. Glöckner, C. Witteman, Thinking \& Reasoning, 16(1), 1-25, (2010).

14. J. Evans, Thinking \& Reasoning, 13(4), 321-339. (2007).

15. D. Marcial, M. Launer, International Journal of Scientific Engineering and Science, 3(12), 1-7, (2019). 
16. C. Kruger, M. Snyman, Analogy between Schrödinger's cat and Performance Measurement. Performance Measurement and Management: Public and Private (pp. 393-400) (London, Performance Measurement Association, 2006).

17. H. Kitzmann, V. Yatsenko, M. Launer, Инновации в менеджменте, 1(27), 22-27, (2021).

18. M. Stöslein, P. Mertens, Punktgenaue Unternehmenskommunikations mit Stakeholder Information systems. DSWR - Datenverarbeitung -Steuern- Wirtschaft -Recht, 25-28. (2004).

19. L. Heinrich, A. Heinzle, R. Riedl, Wirtschaftsinformatik (Berlin, Heidelberg, Springer, 2011).

20. S. A. Beer, Brain of the firm (Wikey and Sons, 1981).

21. A. Gälweiler, Strategische Unternehmensführung (Campus Verlag, 1990).

22. M. Schwaninger, Systems Research and Behavioral Science, 18(2), 137-158 (2001).

23. R. Simons, Levers of Control: How Managers Use Innovative Control Systems to Drive Strategy Renewal (Harward Business School Press, 1995).

24. V. Glushkov, Makroekonomicheskie modeli i printsipy postroeniya OGAS (Moscow: Statistika Publ, 1975).

25. P. Anokhin, Uspekhi Fiziol. Nauk, (1), 19-54 (1970).

26. F. Vester, Die Kunst venetzt zu denken, (dtv Verlag, 2015).

27. G. B. Kleiner, Системная экономика: шаги развития (Научная Библиотека, 2021). 